\title{
Voluntary Pensions Development and the Adequacy of the Mandatory Pension System: Is There a Trade-Off?
}

\author{
Edyta Marcinkiewicz ${ }^{1}$ (D)
}

Accepted: 28 September 2018 / Published online: 5 October 2018

(c) The Author(s) 2018

\begin{abstract}
The policy-makers' efforts to increase the role of voluntary pension systems observed in many countries reflect a more general tendency, which is the privatisation of social risks. The paper examines, from a comparative perspective, to what extent European countries have privatised their pensions in terms of voluntary pension systems. It aggregates and reports data on the assets, membership, and contributions in various pension plans across 20 European countries. To assess the overall relevance of voluntary pension systems in the studied countries, it proposes the Voluntary Pensions Index (VPI), which allows for cross-country comparisons. The paper analyses the relationship between the development of voluntary pensions and pension benefit adequacy in the mandatory schemes form two perspectives: current workers and current beneficiaries. The empirical results suggest that various levels of VPI in the countries studied can be explained by the differences in the pension systems generosity, but only towards the current working-age generation. In countries where the mandatory pension benefits are expected to be smaller, the supplementary pensions play a greater role. The results also imply that in countries with a flatter pension benefit formula adopted in the mandatory system, voluntary pensions are better developed. The adequacy of pension benefits from the mandatory system, as seen from the current beneficiaries' perspective, does not seem to have an impact on the amount of savings and participation in the voluntary programmes.
\end{abstract}

Keywords Pension adequacy $\cdot$ Voluntary pensions $\cdot$ Private pensions $\cdot$ Cross-country studies $\cdot$ Occupational plans $\cdot$ Personal plans

\section{Introduction}

The past decades saw a significant demographic change in many countries in Europe and all over the world. As a result of population ageing, pension systems that rely mainly on the pay-as-you-go formula are no longer capable of ensuring benefits for future pensioners as generous as just recently, while remaining sustainable. A considerable change is

Edyta Marcinkiewicz

edyta.marcinkiewicz@p.lodz.pl

1 Department of Management, Lodz University of Technology, Piotrkowska 266, 90-924 Lodz, Poland 
observed in terms of the goals of the public pension systems. Their adequacy is reduced to maintain the poverty alleviation objective, whereas the realization of the consumption smoothing objective is shifted to the individual. As pointed out in The 2015 Pension Adequacy Report: current and future income adequacy in old age in the EU (European Commission 2015a), the reforms recently implemented in the European countries will result in lower income replacement rates from statutory unfunded schemes in the future. These projections refer to almost all EU member states and apply to low wage earners and high wage earners. To mitigate the effect of such a drop, different measures have been taken. In most of the countries, they comprise raising the statutory retirement age as well as strengthening the role of private occupational and personal pension schemes. The latter is realized through implementing solutions aimed at fostering widespread participation and increasing private pension savings, such as introducing new types of voluntary pension plans and more favourable financial incentives. These measures can be considered as a part of pension privatization and pension marketization. As defined by Ebbinghaus (2015), the first refers to the process of shifting the responsibility for the old age provision to the private sector, and the latter is the process of implementing market and quasi-market mechanisms in the allocation of resources. Marketization can also be identified with recommodification, which is distinguished as one of the dimensions of welfare state change (Crespy 2016; Seeleib-Kaiser 2008). Both concepts-privatization and marketization-are noticeably present in pension reforms carried out in the last two decades in the European countries (see e.g. Kohli and Arza 2008; Carone et al. 2016; Natali 2017 for a review).

Some important questions can be posed in reference to these changes. Do individuals adjust their saving behaviour as a result of the shrinking generosity of public pension systems? If so, is the consumption smoothing objective realized through dedicated voluntary pension programmes or through other forms of long-term savings, which are not taxfavoured, but enable more flexibility in terms of disposing the funds collected before and after reaching the retirement age? Are pension policy measures taken to boost additional retirement savings efficient? To answer these questions, a more complex insight into the landscape of voluntary pensions is required. For further policy recommendation, the key issue is whether the reduction in the public pension generosity per se can induce a behavioural response, i.e. an increase in the household voluntary retirement savings, or whether some additional policy means are required. However, there is a significant empirical gap with reference to this problem, as prior studies very rarely refer to the private, non-obligatory schemes and their relevance as part of pension systems.

The aim of this paper is to examine, from a comparative perspective, the linkage between the generosity of the mandatory pension system and the involvement of individuals into savings in voluntary pension schemes. The contribution of the paper to the existing literature is twofold. First, it improves the knowledge of the current state of supplementary pensions, both personal and occupational. To assess the overall relevance of voluntary pension systems in the studied countries, it proposes the Voluntary Pensions Index (VPI), which allows for cross-country comparisons. It is based on the information collected from numerous local sources and aggregates the data on the assets, membership, and contributions in various pension plans across the European countries. Second, the paper verifies the hypothesis that there is a negative relationship between the benefit adequacy of mandatory pension schemes and the voluntary pensions development captured by different dimensions. It addresses this problem from the cross-country macro perspective, as opposed to the previous literature that focuses mainly on micro data when exploring how mandatory pension programmes influence individuals' participation in voluntary pension schemes. 
The paper is structured as follows. First, the related previous studies are discussed. Then, it presents the database of voluntary pension plans in the European countries. In the next section, the methodology of the construction of the Voluntary Pensions Index is introduced along with the VPI scores for each studied country. The empirical results are verified in terms of an index sensitivity to different parameter settings. Next, the paper analyses the relationship between the VPI scores and different pension adequacy indicators that refer to both: current workers and current beneficiaries. It ends with synthetic conclusions.

\section{Related Literature}

In the current pension systems, voluntary pensions serve as a complement to mandatory ones. Thus, the pension gap that voluntary pension schemes are meant to fill can be perceived through the role of the state, the primary goal of public pension system (poverty alleviation vs. consumption smoothing), as well as institutional settings of a mandatory pension system. In the simplest framework, this can be considered using two basic pension models: Bismarckian and Beveridgean systems (see Bonoli 1997). In the pure form, the first one only provides earnings-related benefits, whereas the latter is based on flat-rate pensions and involves a high level of redistribution. Thus, the function of voluntary pension provision differs in these two models with reference to various groups: low income earners and high income earners, men and women, employed or unemployed (see for example Meyer et al. 2007; Ebbinghaus 2011; Meyer 2014). The same applies to more complex categorisations into pension regimes as proposed in the previous literature (e.g. Bovenberg and Van Ewijk 2012; Esping-Andersen 1990; Marcinkiewicz and Chybalski 2017; Rhodes and Natali 2003; Soede and Vrooman 2008). One can expect that in more liberal pension models where the responsibility for pension adequacy is shifted to individuals, as the public pension benefits are very modest, there is the highest need to encourage voluntary retirement savings. In more social models where the level of intragenerational redistribution is high and the state provides generous benefits especially for low income earners, the voluntary pensions can serve as a consumption smoothing tool for high income earners. In opposition to this model, when benefits strongly reflect previous earnings, voluntary savings are expected to improve the pension benefit adequacy of low income earners. However, such diversely defined role of voluntary pensions in various pension regimes does not fully determine their actual role reflected in the significance of supplementary pensions with reference to different social groups. It may depend on many factors influencing the efficiency of policy measures concerning supplementary retirement savings.

In an ideal world the relationship between mandatory pension adequacy and individuals' involvement in supplementary pension programmes is expected to be perfectly negative. However, when risk and uncertainty are considered, the effect of generosity of pension benefits on saving in voluntary pension plans is not so straightforward. This can be referenced to the uncertainty over the future pension income from mandatory schemes which results from several factors. They may be embedded in the pension system design (e.g. in DC formula) or they can be associated with political risk of changing pension system rules that will influence pension benefit adequacy once the current working-age generation is retired. Previous literature, both theoretical and empirical, usually discusses this issue in a more general framework that involves the linkage between a mandatory pension system and private household savings in general. Blake (2006) as well as Bailliu and Reisen (1998) summarise the theoretical implications of mandatory pensions for savings in the Life Cycle 
Hypothesis framework originated from the works of Modigliani and Brumberg (1954) and Ando and Modigliani (1963). The empirical verification of this relationship in the macro scale refers mainly to the influence of mandatory pensions on private or household saving rates. Some studies suggest that there is a negative effect (see for example Feldstein 1980, 1996). The empirical findings of Bailliu and Reisen (1998) prove that the public pension system generosity defined as pension expenditures relative to the size of the $65+$ reduces household savings. Some other results are delivered by Disney (2006). He states that the contributions to the mandatory system and the level of replacement rates have a positive impact on household savings; however, it mainly depends on the actuarial fairness of the mandatory pension schemes - the more closely the public pension system imitates a private retirement saving, the greater the substitution between household savings and mandatory pension savings. As opposed to the studies conducted in the macro perspective that refer only to household savings in general, there is some literature body on the 'trade-off' between mandatory pensions and voluntary pensions that involve micro data. Voluntary pension plans can be considered as one of the forms of long-term savings that a household can use to accumulate savings for retirement. Le Blanc (2011) conducts a micro-data analysis for eleven European countries based on the SHARE survey to identify the factors that influence the participation in voluntary individual retirement accounts (IRAs). She argues that institutional differences between countries in terms of mandatory pensions explain the agents' propensity to make additional savings for the old age through supplementary pensions. However, not only the current generosity is an important driver in this case, but also the expected changes, i.e. reduction in the pension system generosity. Fernández-López et al. (2010) explore the survey data for eight EU countries to examine factors influencing the probability of saving for retirement on the voluntary basis. Their findings suggest that in the countries where the state provides for retirement in a wider scope (for example France, Italy), the individuals are less willing to save for retirement than households from countries with a greater role of the private sector in the pension system (for example UK, Sweden). Sommer (2007) presents the results of the research conducted using a sample of over 260,000 German households. He examines the probability of having a pension plan in the form of an insurance contract and the wealth in such private pensions. The findings suggest that the self-employed, who are poorly covered by the German pension system, are more eager to save (in terms of higher wealth levels) for retirement in private pension plans. Additionally, the results imply that the employees with the highest income (above the contribution ceiling) do not respond to the lower replacement rates from the public pension system by accumulating greater wealth in private pension plans. Sommer (2007) argues that the possible explanation could be that they choose different saving vehicles.

As stated in the Sect. 1, the issues related to voluntary pensions are rarely addressed in the literature. This arises mainly from data shortages. This paper aims to fill this gap by quantifying the extent to which European countries have developed their voluntary pension schemes. A similar approach, but with reference to all private pension schemes, is presented by De Deken (2013) in his empirical work which covers 21 OECD countries. He proposes the compound index of pension privatization consisting of four components: replacement rate from public pension schemes, assets of private pensions as a share of GDP, private pension expenditure as $\%$ of public expenditure, and contribution rates multiplied by private pensions coverage. However, the study by De Deken (2013) does not distinguish between private mandatory and private voluntary pension schemes; moreover, it is based mainly on the OECD Global Pensions Statistics dataset, which excludes many voluntary pension programmes. 


\section{Empirical Research}

\subsection{Quantitative Data on Voluntary Pension Plans}

As opposed to the public pensions, the access to the information on private voluntary pension plans is much more limited. With regard to the privately managed mandatory pensions, the state involvement is greater and this is also reflected in a more strict supervision and in the obligation of pension plan providers to report more detailed data to central financial authorities. In the case of voluntary pensions, the information of pension plans is not so comprehensively collected and publicly disseminated and often it is not separated from the information of other saving and insurance products. Therefore, different sources are compiled to gather and compare information on voluntary pensions in European countries for the purpose of this study.

Table 3 in the "Appendix" presents the list of data sources used. It also provides some detailed information on the scope of the dataset. It covers 20 countries and combines data from financial authorities, central government departments, associations of pension funds and insurance institutions, central banks, statistical offices, and other. The dataset contains the information on funded pension plans of all kinds (personal and occupational, DB and DC, with various financing vehicles) that meet the following criteria: (1) they have explicit pension purpose and they are run under voluntary pension scheme, (2) they are not financed from the mandatory pension contribution, as optional to another pension scheme, (3) the participation is voluntary to plan members, i.e. an agent can voluntarily opt in or opt out (also in the case of automatic enrolment). Such criteria allow for distinguishing the long-term voluntary pension savings accumulated within the institutional framework of the pension system from 'ordinary' household savings or from mandatory, or quasi-mandatory, pension savings.

Tables 4, 5, and 6 in the "Appendix" present the information about basic quantities characterizing the development of voluntary pension systems in the countries studied as of 2013, i.e. the assets under management in voluntary pension plans (in millions of Euro), membership (in thous. persons) and contributions to the plans paid by both, employers, and employees/plan members (in millions of Euro). The data is presented with the split between personal and occupational plans. However, the numbers given for each country compile different kinds of pension programmes, varying in terms of tax treatment, restrictions on minimal and maximal contributions, imposed frequency of contribution payments, or entities authorized to pay contributions (members only, or also their employers). The only category that can be directly juxtaposed with information from other databases is the membership. OECD (2015a) provides estimates of coverage of private voluntary pension schemes that can be referenced to the presented data. In some cases, there are significant differences. These discrepancies originate from two main causes: (1) the fact that OECD Global Pension Statistics database does not include some voluntary pension programmes; and (2) different categorization of voluntary schemes, especially with reference to the occupational schemes. For example, according to the information obtained from ASF (Insurance and Pension Funds Supervisory Authority), in Portugal, the membership in personal pension plans expressed as \% of working age population reaches $35.4 \%$, whereas OECD (2015a) provides the coverage rate equal to $4.0 \%$. The latter is significantly underestimated because the value does not include PPR plans (Planos poupança-reforma) in the form of insurance contracts, which are the most widespread personal plans in Portugal. 
A considerable effort has been taken to ensure that the dataset concerning the quantitative information about voluntary pension plans in 20 countries is comprehensive and reflects the current state. However, in some cases, the presented values are biased, which arises from the data availability. The more detailed methodological information is reported in Table 3 in the "Appendix". Most of such cases refer to the underestimation of given numbers due to the exclusion of particular types of voluntary plans. For example, data for Austria does not include occupational plans in the form of group and individual insurance contracts. Similarly, for Hungary information about contributions to NYESZ personal accounts is not available. In the case of Belgium, group insurance contracts of the "Branch 23 " type are not included in the analysis. Nonetheless, the data gaps do not affect significantly the estimated values as the omitted types of plans in each country represent only a small fraction of all voluntary plans.

For some countries, the reported values can be also overestimated. As to the rule, the plans that are financed from mandatory pension contribution are not taken into account in this study. However, there are some particular programmes, which can be based on both, mandatory and voluntary contributions. This is, for example, the case of the S2P program in the United Kingdom, where additionally to voluntary contribution, also a part of the mandatory contribution can be transferred to. At the aggregated level, it was not possible to separate fully voluntary contributions collected under S2P from mandatory ones. This also applies to countries where voluntary pension insurance is combined with saving for additional purposes such as severance pay. While in Austria, the severance pay accumulated by the employer is collected in dedicated funds, which are not included in the presented dataset as voluntary funds, in Italy the funds from TFR provisions (Trattamento di Fine Rapporto) may - although not necessarily have to- be included as the assets of pension funds. As the disaggregation of TFR assets and other voluntary pension assets is not available, they are presented together. In the case of Slovakia, employers of workers of hazardous professions are obliged to pay contributions to the third pillar. As there is no possibility to separate these contributions, they are included in the presented numbers.

\subsection{Voluntary Pensions Index}

Basing on the gathered data, this paper aims to evaluate the size and relevance of voluntary pension systems in the countries studied using three separate components (dimensions): (1) assets (as \% of GDP), (2) participation rate, and (3) contribution rate.

The first one, i.e. assets as a share of GDP, is typically used when the relevance of any funded pension scheme is considered. This quantity is a basic indicator as it expresses the amount of pension capital saved with reference to the size of the economy. However, in comparative analyses, especially those involving cross-country perspective, the ratio should not be used as the only gauge, due to certain disadvantages. It depends strongly on the time of operation of a given pension scheme. Comparing countries with a long tradition in voluntary pension plans with countries where they have been established very recently is pointless. The same applies to the schemes in different maturity phases (accumulation or decumulation of the funds). Also, comparisons that involve a short time perspective may be biased, as the value of the assets is sensitive to the financial market fluctuations.

The second component used when the relevance of voluntary pension schemes is addressed is participation rate. In this study, it is defined as the number of pension plans relative to the size of the 15-64 age group, which can be regarded as the working-age population; however it is an approximate reference, as in many countries the 
pensionable age is higher than 65 . Participation rate can be identified with the coverage rate. Nonetheless, there is a substantial difference between these two ratios. Coverage rate expresses the number of persons covered in a particular pension scheme as $\%$ of the working-age population. But the aggregation of different kinds of pension schemes limits the capability to evaluate a common coverage rate. It is possible only when agents are not allowed to participate in more than one pension plan. Otherwise, at the aggregated level the identification of such doubled or tripled cases is usually not achievable. Participation rate informs about prevalence and accessibility of voluntary pension plans across the working-age population. As seen from the macro-perspective it reflects the potential of the voluntary pension system to ensure pension provision complementary to the mandatory system. However, a widespread participation in the population does not imply significant aggregated savings. This is the case especially of these pension schemes, which do not impose on the member (or the employer) the obligation to pay regular or irregular contributions to the pension plan. In some pension schemes, even the majority of members can remain inactive. The problem of such pension plans, which are not contributed with payments, can be regarded as a bias in the cross-country comparisons, but inevitable when the aggregation of personal and occupational schemes at the country level is involved.

The third dimension that reflects the role of supplementary pension provision is contribution rate. In this study, it is expressed as the annual average contribution per plan with reference to the annual net average wage. Annual contribution per plan is calculated dividing the total amount of contributions (to all the aggregated pension schemes, regardless their type) by the total number of voluntary pension plans. To enable crosscountry analyses the contribution is referred to the average economy-wide earnings. Such ratio, even though it is obtained using aggregated values, can be interpreted as a rough equivalent of the voluntary pension saving rate. It has some advantage over other typically used indicators such as total contributions as a share of GDP, or average contribution calculated across the whole working-age population or the number of employed persons. Contribution rate used in this study is independent on the coverage of plans in the population. It reflects the actual saving activity only of the members of voluntary pension plans. When the average amount contributed to the plans is below expectations it may indicate that a given scheme operates ineffectively and some means are necessary to boost retirement savings. In a pension scheme that is poorly covered by the population but demonstrating high saving rates, and in a scheme that is widely covered but with relatively inactive members in terms of contributions paid, the total amounts of contributions can be very similar. The same can be observed at country level when the schemes are aggregated. Total contribution as \% of GDP as an indicator of the development of voluntary pension systems excludes the ability to distinguish between the situation when low contribution results from low participation rate (which could be driven e.g. by hindered accessibility of pension plans) and the situation when it arises solely from agents' propensity to save. As in this study participation rate is featured as a separate dimension, its impact is eliminated from the contribution rate.

This study aims at measuring the size of non-mandatory pension schemes in the European countries. To achieve this goal the Voluntary Pensions Index (VPI) is proposed. It includes all three dimensions describing the size and the level of development of voluntary pensions in studied countries as defined earlier in this section i.e. assets relative to GDP, participation rate as the number of pension plans in relation to the size of the 15-64 population, and contribution rate given as the ratio between annual contribution per plan and annual net average earnings. 
The components express different quantities and ranges, so to provide comparability, their values have been scaled to the [0;100] interval before including in the VPI. Following Alonso-Fernandez et al. (2017), the normalization formulas are expressed as follows:

$$
z_{i j}= \begin{cases}0 & \text { for } x_{i j}<x_{j}^{\min } \\ 100 \% \cdot \frac{x_{i j}-x_{j}^{\min }}{x_{j} \max _{-x_{j}} \min } & \text { for } x_{j}^{\min } \leq x_{i j} \leq x_{j}^{\max } \\ 100 & \text { for } x_{i j}>x_{j}^{\max }\end{cases}
$$

where $z_{i j}$ denotes a scaled value of $j$-th component for the $i$-th country, $x_{i j}$ stands for the value before normalization, $x_{j}^{\mathrm{min}}$ is a (subjective) lower boundary of $j$-th component, and $x_{j}^{\max }$ is a (subjective) upper boundary, respectively. A standard normalization procedure as $x_{j}^{\min }$ and $x_{j}^{\max }$ employs the minimal and maximal values in a set of observations, and it measures the distance between a given observation and the worst observation in a group relative to the distance between the best and the worst observations. However, such transformation relates all the scaled values to the extreme observations in a given set and at the particular moment of time. Thus, the results of normalization are incomparable across different groups of objects and across time. To avoid this problem the subjective lower and upper boundaries are included.

In the case of normalized values of assets (as $\%$ of GDP) $x_{j}^{\min }$ is equal to $0 \%$, whereas $x_{j}^{\max }$ is equal to $60 \%$. In the studied group of countries, the voluntary pension assets exceed the upper boundary only in the United Kingdom (138\%), whereas in Belgium-which is the second country in the sample in terms of the assets value-they are very close to it (52\%). The threshold of $60 \%$ can be also referenced to the weighted average of assets (as $\%$ of GDP) accumulated in both, mandatory and voluntary private pension schemes, in OECD countries, which reached over 120\% in 2015 (OECD 2016).

The participation rate is scaled using the same thresholds of $x_{j}^{\min }$ equal to $0 \%$ and $x_{j}^{\max }$ equal to $60 \%$. The upper value is adopted with reference to the average employment rate in the EU in age class 15-64, which, according to Eurostat, ranges between 64 and $66 \%$ in the 2010-2015 time span. Thus, the upper limit set as 60\% corresponds to the hypothetical scenario when almost every employed person is a member of one voluntary pension plan. In the group of studied countries, only Czechia exceeds this threshold with participation rate equal to 69\%, but in Spain and Iceland, the ratio is not much below the upper boundary (59\% and $53 \%$, respectively).

The limits set for normalizing the contribution rate are adjusted to the observed real values, and these in the studied group vary between $0.5 \%$ (Slovakia) and 22\% (United Kingdom). Consequently, the adopted thresholds equal $0 \%$ for $x_{j}^{\min }$, and $20 \%$ for $x_{j}^{\max }$. The upper limit, in this case, can be referenced to the limits on deductibility of contributions in the tax-favoured schemes or the restrictions concerning maximum amounts of the contributions. However, these vary significantly across particular pension schemes in the studied countries (see OECD 2015b, c for a review). Nonetheless, the upper limit of $20 \%$ seems to fairly reflect the attainable maximum level of contribution to voluntary pension plans. For a majority of countries, this value is lower than the mandatory pension contribution rate, which also ranges significantly (in some countries there are non-contributory public pension systems, as they are financed by taxes). For example, in Belgium, it amounts to $16.4 \%$ of gross earnings, whereas in Hungary it is 34\%, and in Italy 33\% (see European Commission 2015a; OECD 2015a for a review). 
All three transformed variables are compiled into the single Voluntary Pension Index (VPI). It is given by the following formula:

$$
V P I_{i}=w_{1} \cdot \operatorname{ASSETS~}_{i}+w_{2} \cdot \text { PART }_{i}+w_{3} \cdot \operatorname{CONTR}_{i}
$$

where $\operatorname{ASSETS}_{i}$ denotes the normalized values of assets as a share of GDP in $i$-th country, $P A R T_{i}$ stands for (normalized) participation rate expressed as number of voluntary pension plans relative to the size of 15-64 population, $C O N T R_{i}$ denotes (normalized) contributions per plan with reference to the net average earnings, and $w_{1}, w_{2}, w_{3}$ are the weights of components in the index (their sum is equal to 1 ).

The weights in formula (2) reflect the importance and contribution of each of the three components to the total score of the index. The components proposed for the VPI are equally weighted, i.e. $w_{1}=0.333, w_{2}=0.333$, and $w_{3}=0.333$. It makes the formula (2) a simple arithmetic average.

Figure 1 presents the VPI scores for 20 European countries. The scores are decomposed according to the input represented by each component. In Table 7 in the "Appendix", the scaled values of all the three components, as well as the total VPI scores, are reported. As can be seen, there are significant differences in the studied group with regard to the development of voluntary pension system. The highest VPI scores are reported for the United Kingdom and Belgium, and they amount to 88.4 and 70.8 , respectively. In the first case, the assets and contributions are of maximum levels (scores 100.0 for ASSETS and CONTR). Belgium is characterized by relatively large assets and participation rate; however, the contributions to voluntary pension plans are approximately half less than in the United Kingdom. A group of countries from the CEE region (Slovakia, Latvia, Poland, Bulgaria, Croatia, Lithuania, Romania) closes the ranking. Their scores are less than 15.0. The arithmetic mean of VPI for the group studied amounts to 29.6, which indicates a quite low average level of development of voluntary

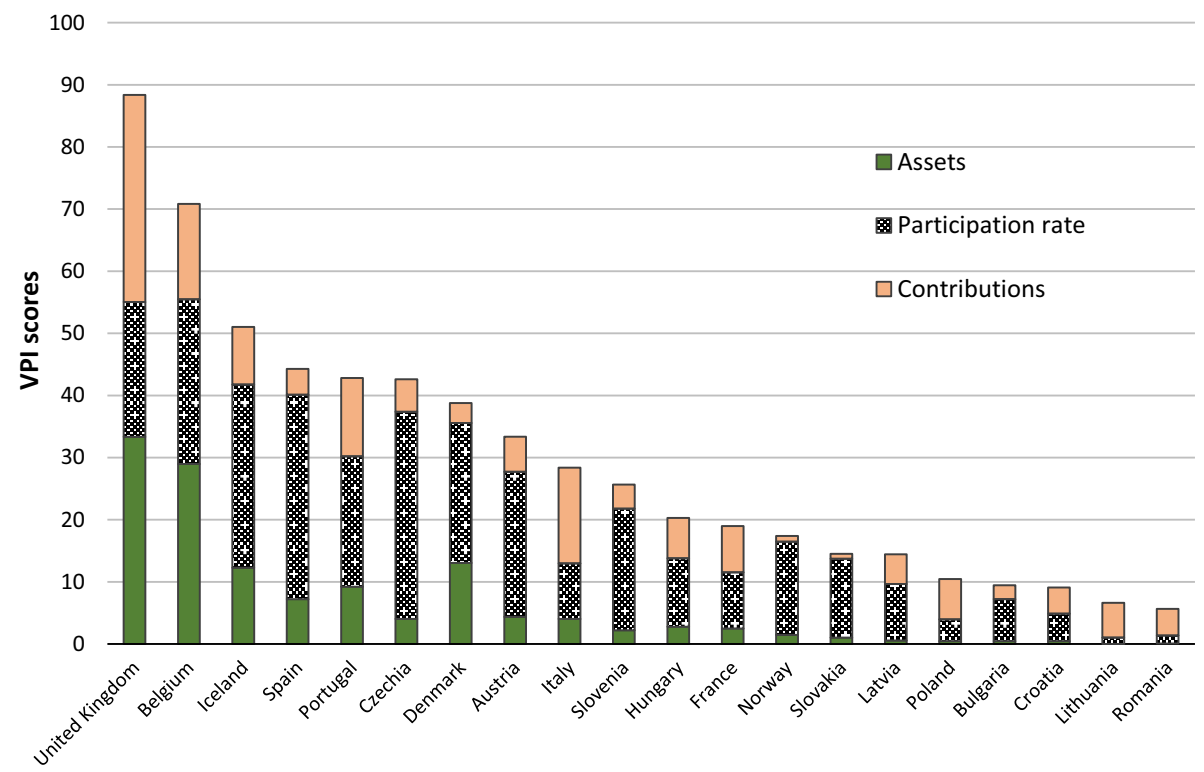

Fig. 1 Decomposition of the Voluntary Pensions Index (VPI) 
pension schemes. However, the dispersion is considerably large, as the standard deviation from the mean is 21.7 .

The decomposition of the index into three components allows to investigate the proportions between particular dimensions. It refers especially to the relation between participation rates and contributions. Their analysis enables some interesting findings. For example, there are some countries such as Spain, Czechia, Iceland, where participation rates are very high, and at the same time, contributions are relatively small. This may imply that channels of pension products distribution work effectively, however, the extensive participation does not entail actual saving, so additional incentives or financial education may be needed. There are also countries, such as the United Kingdom and Italy, where the relatively small participation rates are accompanied by high levels of contributions. This, in turn, may indicate that the solutions implemented to encourage voluntary pension savings and to make them attractive compared to other forms of long-term savings are efficient. However, such conclusions can be formulated only after a more profound country case study, which also involves micro data analysis. Large contributions together with participation limited to a small fraction of the working age population can also imply that the incentives to save are targeted only towards the high-income earners, and other groups do not respond to them adequately. Additionally, one can notice that for many countries, especially at the right side of the graph presented in Fig. 1, the input of assets to the total VPI score is very small or even negligible. The possible explanation is short tradition of voluntary pension programmes in these countries or the lack of their importance in the past. Nevertheless, whereas the contributions and participation determine the potential of voluntary pensions to supplement the income at retirement with reference to the current working age population, the assets reflect their capability to improve the pension benefit adequacy as seen at the moment. The latter is very much limited especially in the CEE region, but also in countries such as France and Norway.

\subsection{Robustness Check}

Formulas (1) and (2), that the proposed index is based on, require nine parameters. These are: $x_{j}^{\min }, x_{j}^{\max }$ and $w_{j}$ corresponding to each of the three components of the VPI. The previous section provides a justification for establishing particular values of these parameters. However, they are still to some extent subjective. To verify the robustness of the index, its sensitivity to different parameters setting has been tested. A Monte Carlo simulation has been used to investigate the effect of various combinations of parameters on the final VPI score. The method is based on random sampling from a fixed set of values. It is regarded as a more sophisticated tool than 'what if' analysis, which in the case of a relatively large number of parameters whose values range in wide intervals can be somewhat problematic and unreliable. Table 1 presents the tested ranges of parameters. In the case of two components: ASSETS and PART, the upper limits for normalization $\left(x_{j}^{\max }\right)$ are investigated within the range $50-70 \%$, whereas for CONTR they vary between 10 and $25 \%$. The lower limits for scaling are established at the constant level of $0 \%$. The tested weights are referred to $w_{1}$ corresponding with ASSETS. The remaining two weights $\left(w_{2}\right.$ and $\left.w_{3}\right)$ are assumed to be equal. As discussed in the previous section, the input of assets as a share of GDP to the VPI can raise some concerns especially connected with its susceptibility to various factors such as time. Therefore, the weight attributed to this component in simulation tests ranges between 0.15 and 0.35 . This interval enables to investigate the input of ASSETS in the scope from the relatively minor impact to an impact slightly higher than the other two 
Table 1 Parameters setting for the VPI sensitivity analysis

\begin{tabular}{llll}
\hline & ASSETS & PART & CONTR \\
\hline $\begin{array}{l}\text { Basic scenario } \\
x_{j}^{\min }(\%)\end{array}$ & 0 & 0 & 0 \\
$x_{j}^{\max }(\%)$ & 60 & 60 & 20 \\
$w_{j}$ & 0.333 & 0.333 & 0.333 \\
$\begin{array}{l}\text { Ranges tested } \\
x_{j}^{\min }(\%)\end{array}$ & 0 & 0 & 0 \\
$x_{j}^{\max }$ & $50-70 \%$ (with accuracy of $1 \%)$ & $50-70 \%($ with accuracy & $10-25 \%($ with \\
& & of $1 \%)$ & $\begin{array}{c}1 \% \\
1 \%\end{array}$ \\
$w_{j}$ & $0.15-0.35$ (with accuracy of \\
\hline
\end{tabular}

components. Weights for participation rate and annual contribution are adjusted accordingly in the tests, under the premise that the corresponding components are equally relevant to the VPI, as there is no particular reasoning for a special preference of one of the dimensions above another.

Different combinations of parameters from the ranges indicated in Table 1 have been randomly selected with the number of draws equal to 10,000 , and the probability determined by the discrete uniform distribution. Consequently, for each country, 10,000 VPI scores, corresponding to the extracted sets of parameters, have been calculated. Figure 2 presents the summary statistics for the VPI scores as a result of parameters sampling (a more detailed information on the distribution of the results is provided in Fig. 7 in the "Appendix"). In all of the twenty cases, the obtained average score is very close to the score determined by the original parameter setting (basic scenario). Additionally, the figure reports the dispersion of the results determined by the interval of two standard deviations around the mean. According to the Empirical Rule often addressed to in statistics, if the distribution of observations is normal, then we can expect approximately $95 \%$ of measurements to fall into this interval (see Mendenhall et al. 1982). When there is no assumption

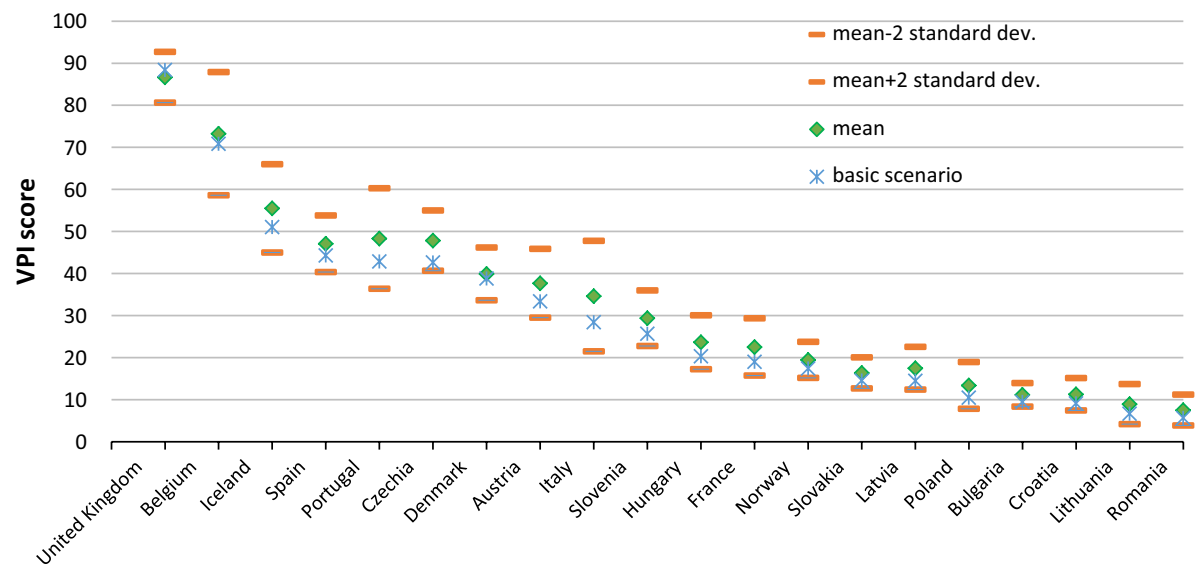

Fig. 2 Summary of the simulation tests 
on the measurements distribution, then Chebyshev's theorem can be applied. It states that at least $75 \%$ of values lie within two standard deviations of the mean. As it is shown in Fig. 2, the variation around the mean is diversified across countries. The results for Belgium, Portugal and Italy are the most vulnerable to different parameter settings. However, the order of countries in terms of VPI under different combinations of parameters does not seem to be noticeably disturbed, as well as the actual VPI scores.

\subsection{VPI Versus the Adequacy of Mandatory Pension Systems}

As presented in the previous sections, there are considerable differences among countries with reference to voluntary pension development reflected by the proposed index. The ratio between the standard deviation and the mean of VPI is equal to 73\%, which indicates high variability across countries. To explore whether the source of this heterogeneity can be found in different institutional settings regarding mandatory pension systems, some analyses have been carried out that deal with the issue of the pension system generosity. It can be identified with pension benefit adequacy, which is most commonly measured by the replacement rate. It is defined as a ratio between the pension benefit and the income from work. As shown in numerous studies, the replacement rate can be expressed in a variety of ways (see for example Bajtelsmit et al. 2013; Borella and Fornero 2009; Grech 2013; Wolf et al. 2014; Zohlnhöfer et al. 2013).

In this study, first, the adequacy is examined from the perspective of the current working-age generation. This group contributes the most to the growth of voluntary retirement savings accumulated in the supplementary pension plans. However, the assessment of the adequacy of the current pension system with reference to the working-age generation is very difficult. This results from the fact that this notion applies to the pension benefit and its sufficient level. Thus, in the case of the current workers, one can only consider the expected (future) pension benefit adequacy. It can be expressed by theoretical replacement rates calculated for a hypothetical worker under different assumptions for his or her career path and income as well as under current pension system rules. Such modelled replacement rates for EU countries have been proposed by the European Commission (2015a) as the Theoretical Replacement Rates (TRR). However, this ratio refers to the modelled benefits from pension schemes, which are mandatory, typical or have widespread coverage. This means that TRR, for some countries, includes voluntary pension schemes (if the number of workers enrolled is large enough), whereas for other, it does not. It affects both-the usefulness of this ratio to verify the relationship between pension adequacy and voluntary schemes development, as well as the comparability of the data analysed with this regard. That is why, for the purpose of this study, another replacement rate is employed, namely the Pension Replacement Rate (PRR) given by OECD (2015a). It is calculated for a modelled 20-year-old individual, an average wage earner (PRR is also available for 0.5 and 1.5 of average wage earners), single, entering the labour market in 2012 and continuing the career without a break, until retirement age as stipulated by the law in each country. PRR is published in gross, as well as in net version. An important advantage of PRR with reference to this study is that it distinguishes between replacement rates from public, mandatory private, and voluntary schemes. The conducted empirical analysis employs PRR from all of the mandatory pension schemes (i.e. public and private). However, the limitation of this approach is that OECD estimates of the replacement rates do not cover all of the countries included in this study, so the analysed sample is reduced (Bulgaria, Croatia, 


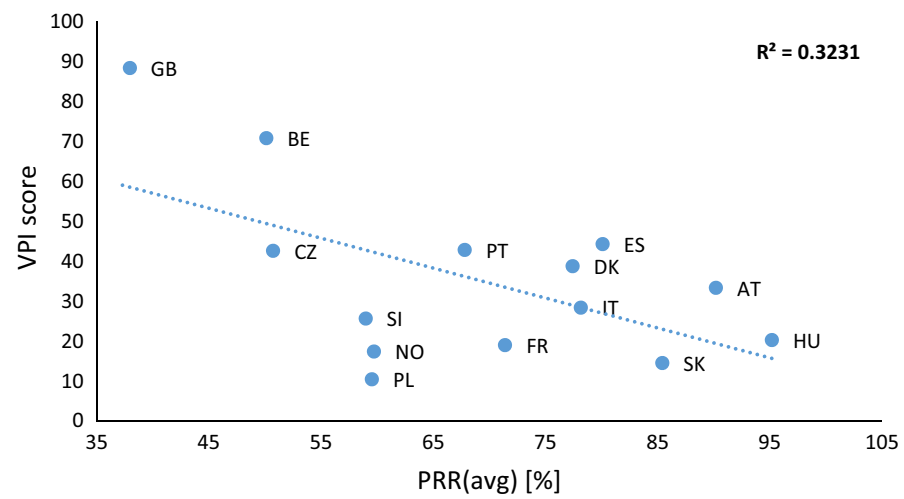

Fig. 3 VPI versus modelled replacement rates for average income earner (2013)

Table 2 Pearson correlation coefficients between VPI and its components and pension adequacy indicators (2013)

\begin{tabular}{|c|c|c|c|c|c|c|}
\hline & \multicolumn{4}{|c|}{ Adequacy from the current workers' perspective } & \multicolumn{2}{|c|}{$\begin{array}{l}\text { Adequacy from the } \\
\text { current beneficiaries' } \\
\text { perspective }\end{array}$} \\
\hline & PRR (low) & PRR (Avg) & PRR (High) & $\begin{array}{l}\text { PRR } \\
\text { (low)-PRR } \\
\text { (high) }\end{array}$ & PE/GDP/ODR & ARR \\
\hline VPI & -0.23 & -0.57 & -0.58 & 0.48 & 0.22 & -0.06 \\
\hline Assets & -0.34 & -0.59 & -0.60 & 0.42 & 0.18 & -0.10 \\
\hline Participation & 0.15 & -0.26 & -0.30 & 0.47 & 0.00 & -0.02 \\
\hline Contributions & -0.51 & -0.54 & -0.50 & 0.17 & 0.42 & 0.06 \\
\hline
\end{tabular}

Bolded values indicate significance at the $5 \%$ level

Latvia Lithuania, and Iceland are excluded). To account for the differences in taxation rules between countries, only net PRR are used.

Figure 3 presents correlation plots that compare the VPI scores with net PRR calculated for an average wage earner and denoted by PRR (avg). As expected, a negative relationship is observed. This implies that the higher replacement rate from the mandatory pension system (as projected for current workers), the smaller the relevance of voluntary pensions. The results are in line with a previous literature body on the determinants of household savings in general, analysed from both, micro and macro perspective (see Alessie et al. 1999; Attanasio and Rohwedder 2003; Bailliu and Reisen 1998; Feldstein 1980, 1996; Feng et al. 2011; Lachowska and Myck 2015; Vaillancourt et al. 2015).

Table 2 reports the Pearson correlation coefficients between VPI and PRR calculated for an average income earner (average wage), as well as for a low income earner ( 0.5 of the average wage) and a high income earner (1.5 of the average wage), denoted by PRR (low) and PRR (high), respectively. The relationship is strong only for PRR (avg) and PRR (high), but not for PRR (low), which indicates that the pension adequacy for low income earners and for high income earners differentiate countries in a different manner with reference to voluntary pensions relevance. To further explore this problem, the pension gap 


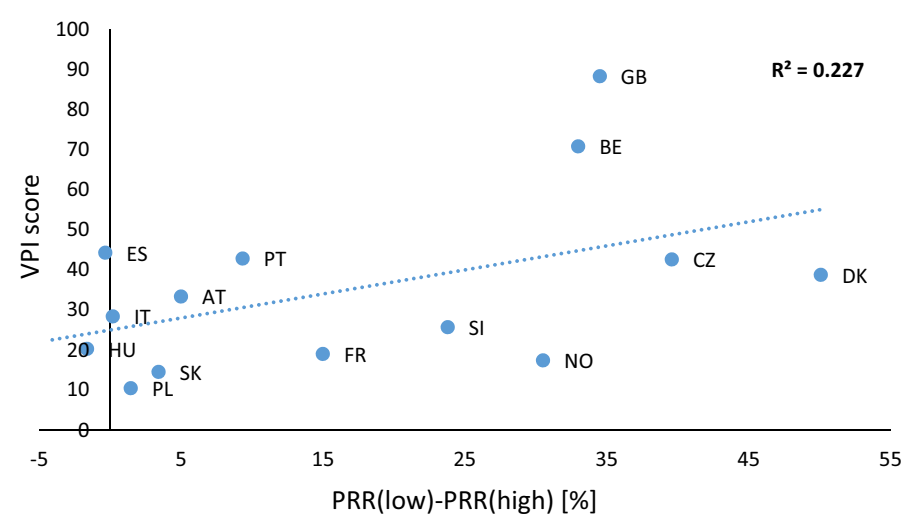

Fig. 4 VPI versus the adequacy gap (modelled replacement rates) between low-income and high-income earners (2013)

between high and low income earners is examined. Figure 4 present the correlation plot for this gap, defined as the difference PRR (low) - PRR (high), and the VPI scores. A smaller gap indicates more earning-related pensions (Bismarckian model), whereas a larger gap implies more redistributive pension schemes (Beveridgean model). There is a positive correlation between both studied variables; however, it is not as strong as in the case of PRR (avg). Nonetheless, this moderate relationship suggests that the less earning-related mandatory pensions, the bigger the scope of voluntary retirement savings, which is in line with the findings by Disney (2006).

Assessing the pension system generosity towards current beneficiaries is usually easier than for the current workers, as it is based on the ex post analysis of pre-retirement income and pension benefits. It employs either micro-data or aggregated quantities for the whole economy. However, especially at a micro-level, it is difficult to separate pension benefits from other incomes in the old age, and further distinguish between pension benefits obtained from various schemes: mandatory, voluntary, public and private. This problem refers to the key indicators of pension adequacy according to the Open Method of Coordination, such as the Median Relative Income of elderly people (MRI) or the Aggregate Replacement Ratio (ARR) calculated using the EU-SILC database and published by Eurostat. At the macro level, for EU countries, two main indicators of pension adequacy are available: the Benefit ratio (BR), and the Gross Average Replacement Rate (GARR), both published in the 2015 Ageing Report (European Commission 2015b). However, they account for benefits only from public earning-related pensions or all public pensions, including disability and survivor pensions. That is why this study uses a different measure of pension generosity, which is the ratio between pension expenditure as a share of GDP and old-age dependency rate (PE/GDP/ODR) as defined by Marcinkiewicz and Chybalski (2014). It may be referenced directly to the intergenerational division of the output, as it can be used to assess whether the elderly generation receives an adequate part of GDP relative to its size. Both components of this ratio are published by Eurostat, and what is vital, the data on pensions expenditures (from ESPROSS database) is available separately for public old age pensions.

For the purpose of this study, two indicators of pension system generosity as seen from the current pensioners' perspective are employed: PE/GDP/ODR and ARR. The first refers to the macro scale, the latter to the micro scale. However, as mentioned previously, ARR 


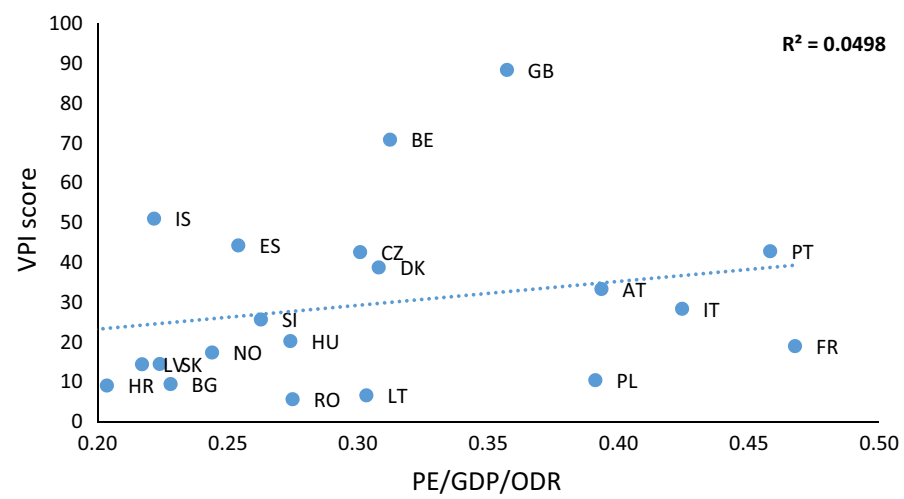

Fig. 5 VPI versus pensions expenditures adjusted for the relative size of the elderly population (2013)

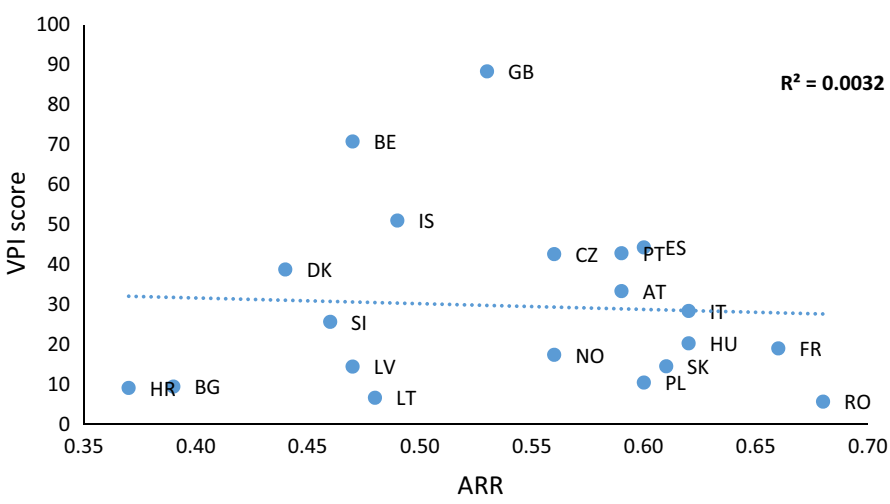

Fig. 6 VPI versus the Aggregate Replacement Ratio (2013)

should be interpreted with caution, since it includes public old-age pensions, survivors pensions and personal pensions. The possible positive correlation could be biased in such a case.

As reported in Fig. 5, no connection can be found between the VPI scores and the PE/ GDP/ODR ratio. The relationship between the VPI and the studied indicator of pension adequacy, with reference to the whole elderly population, expressed by the Pearson correlation coefficient reported in Table 2, is very weak. A similar result is also obtained for ARR. The correlation plot presented in Fig. 6 clearly indicates that the scope of voluntary pensions is independent of the replacement ratio. It denotes that the pension system generosity towards current pensioners does not explain the differences in the role of voluntary pensions in the countries studied.

To examine the relationships between particular dimensions of VPI and the generosity of pension systems, the correlation coefficients for voluntary pensions assets, participation and contribution are also given. According to the results reported in Table 2, assets and contributions to voluntary pension plans are mainly responsible for the observed relationships between VPI scores and pension system adequacy indicators as seen from the current workers' perspective. Participation in voluntary pension programmes is not so much related to the generosity of pension system. 


\section{Conclusions}

To avoid a substantial drop in the standard of living agents are required not only to work longer, but also to make additional provisions for income in old age as a supplement to mandatory pension contribution. To answer the question whether the level of savings and coverage is sufficient to achieve the goal of consumption smoothing with reference to the macro perspective, first, an assessment of the current state of voluntary pensions is required, and second, the scope of the actual need to complement mandatory retirement savings should be evaluated.

This study presents dataset comprising main indicators of the relevance of the voluntary pension programmes collected for 20 European countries. It also proposes the Voluntary Pensions Index that allows for cross-country comparisons in this respect. It captures three dimensions: prevalence, contribution rate and its worth relative to the size of the economy. The results of the VPI scores reflect the importance of voluntary pensions in the countries studied. However, this importance can be regarded only in terms of the scope of participation measured by coverage and savings in voluntary pension plans, as the study is conducted for the aggregated data, and thus, it represents a macro perspective. It does not refer to the expected share of voluntary pensions in the retirement income, because such assessment would require a micro approach. Moreover, in such a case a reference to the retirement income from the mandatory pension schemes would be necessary. It should be stressed that the proposed index is not of a 'the higher the better' kind. Its normative interpretation for each country should take into consideration the actual necessity to foster voluntary pensions. Some countries may secure adequate pension benefit replacement rates from the mandatory public or mandatory private pension schemes. As pension adequacy is a gradable category, pension systems across the group studied differ in terms of a need to develop voluntary pensions. Nonetheless, the presented index delivers synthetic information on the performance of voluntary pension schemes in European countries and it can be used e.g. for further comparative analyses of welfare state changes as well as serve as a basis for policy recommendation in the area of efficient solutions to boost additional savings for old age.

The paper analyses the relationship between the development of voluntary pensions and pension benefit adequacy in the mandatory schemes from two perspectives: current workers and current beneficiaries. The empirical results suggest that various levels of VPI in the countries studied can be explained by the differences in the pension system generosity, but only towards the current working-age generation. This linkage is strong and negative. In countries where the mandatory pension benefits are expected to be smaller, the supplementary pensions play a greater role. However, also some more profound qualitative analysis for the countries studied is required to answer the question to what extent this adjustment is driven by special policy means towards promoting voluntary participation in pension programmes, and to what extent this mechanism is automatic. There is still a significant variation unexplained by the differences in replacement rates, and this can result from different policies and the design of voluntary pension schemes. The results also suggest that in countries with a flatter pension benefit formula adopted in the mandatory system, voluntary pensions are better developed. This may imply that supplementary pension plans serve as a consumption smoothing tool for a group, which is anticipated to have lower income replacement in the old age, i.e. the better-salaried agents, who have a stronger urge to smooth consumption.

The adequacy of pension benefits from the mandatory system, as seen from the current beneficiaries' perspective, does not seem to have an impact on the amount of savings and 
participation in the voluntary programmes. This supports the view that the saving behaviour of the working generation is driven not by naïve expectations suggested by the situation of current pensioners, but is based on more rational grounds.

The analysis of the different levels of voluntary pension development across the studied countries raises questions about some additional possible factors that can be derived from the design of mandatory pension schemes, apart from the pension system generosity. Namely, in the majority of countries with mandatory private pensions, both occupational and personal, the voluntary pensions are very poorly developed. These are: Slovenia, France, Norway, Slovakia, Latvia, Poland, Bulgaria, Croatia, Lithuania, Romania. Only in Iceland and Denmark voluntary personal pension schemes operate as an important complement to mandatory occupational pension schemes. These findings can be referenced to previous studies that support the view that mandatory private pensions crowd out voluntary ones (see Dushi and Webb 2004; Inkmann et al. 2011).

A closer look at other features embedded in pension system arrangements, especially those referring to mandatory public pensions, does not allow to distinguish further patterns which could be useful in explaining the diversity of the levels of VPI across the group studied. The countries covered by this study vary when it comes to the pension systems financing (contributory vs. tax financing), pension contribution rates, minimum or basic pension arrangements and corresponding eligibility criteria, pensionable age, earnings-related public pensions etc. (for an overview see European Commission 2015b; OECD 2015a). However, basing only on a rough assessment, one can conclude that none of these factors is clearly and unambiguously related to the order of countries in the VPI ranking. It seems to be more justified to state, that not the architecture of a public pension system itself induces the development of voluntary pensions, but its performance which is reflected inter alia by the adequacy of public pension benefits.

The results obtained can be referenced also to the design of voluntary pension schemes which comprises a variety of solutions in terms of the number of available programmes and their types (personal vs. occupational). In the analysed group there are countries with a mix of different personal and occupational programmes with no prevailing type in terms of coverage (e.g. the UK, Spain, Italy, France), countries with predominant role of personal plans (e.g. Iceland, Denmark, Hungary, Lithuania), and countries with predominant role of occupational plans (e.g. Slovenia, Romania). Yet, each group exhibits a great diversity when it comes to the VPI scores. Thus, the results of this study also do not allow to conclude that a given type of voluntary pension plans (occupational or personal) fosters greater role of voluntary pension provision at the aggregated level.

Acknowledgements This paper forms a part of the project funded by the National Science Centre (Poland) under Grant Number DEC-2014/15/D/HS4/01238.

Open Access This article is distributed under the terms of the Creative Commons Attribution 4.0 International License (http://creativecommons.org/licenses/by/4.0/), which permits unrestricted use, distribution, and reproduction in any medium, provided you give appropriate credit to the original author(s) and the source, provide a link to the Creative Commons license, and indicate if changes were made.

\section{Appendix}

See Fig. 7 and Tables 3, 4, 5, 6 and 7. 

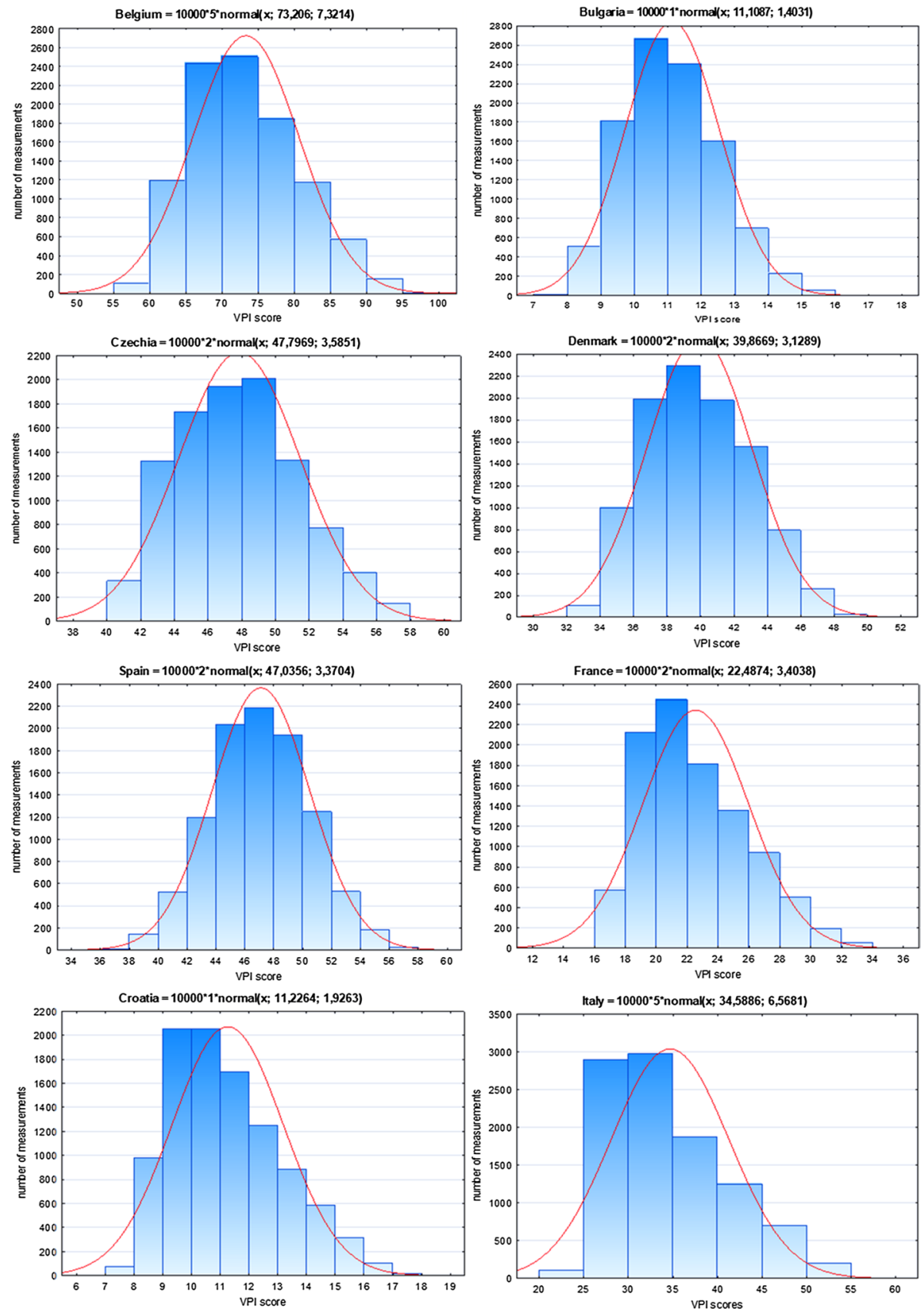

Fig. 7 Distribution of the simulation results 

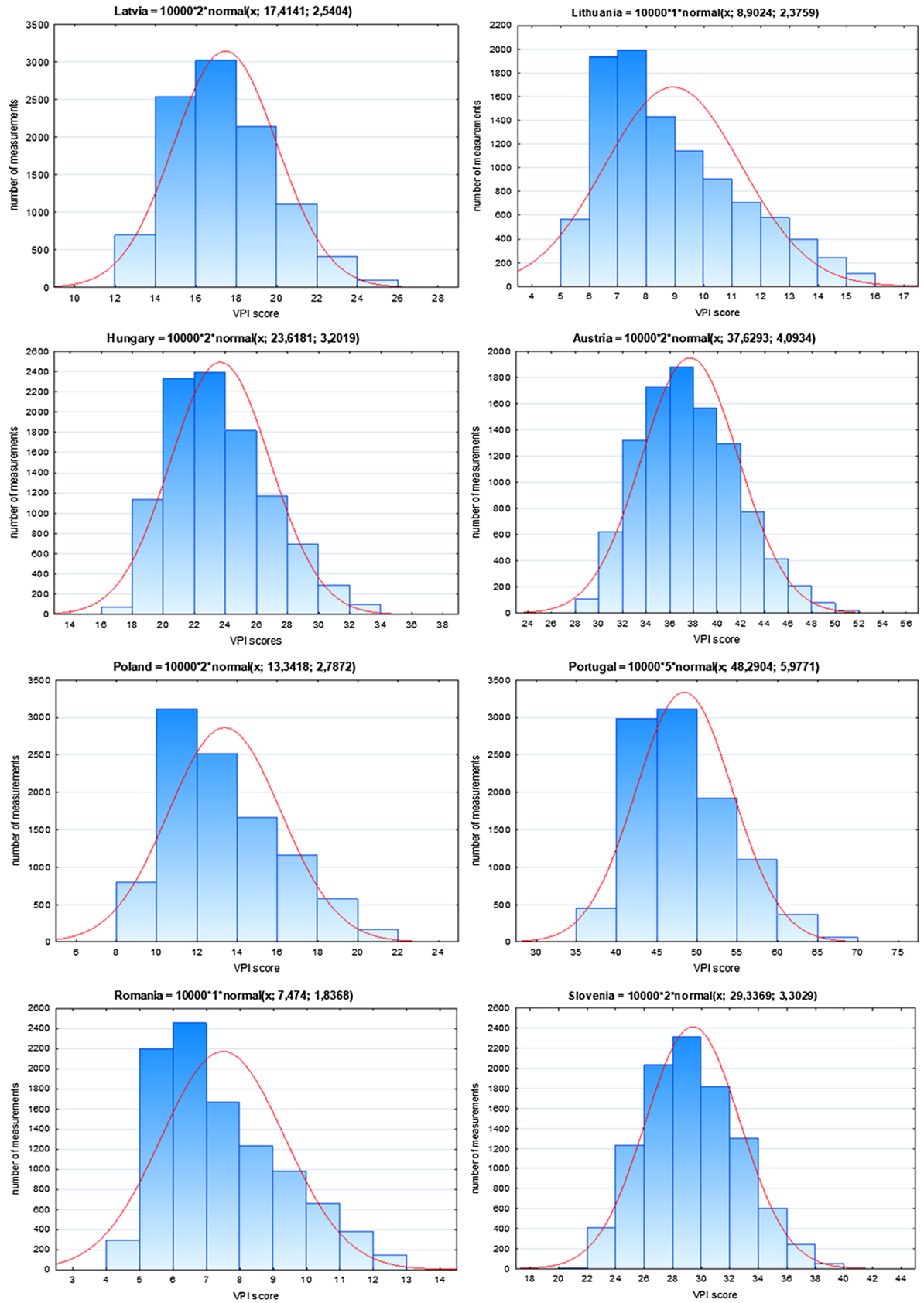

Fig. 7 (continued) 

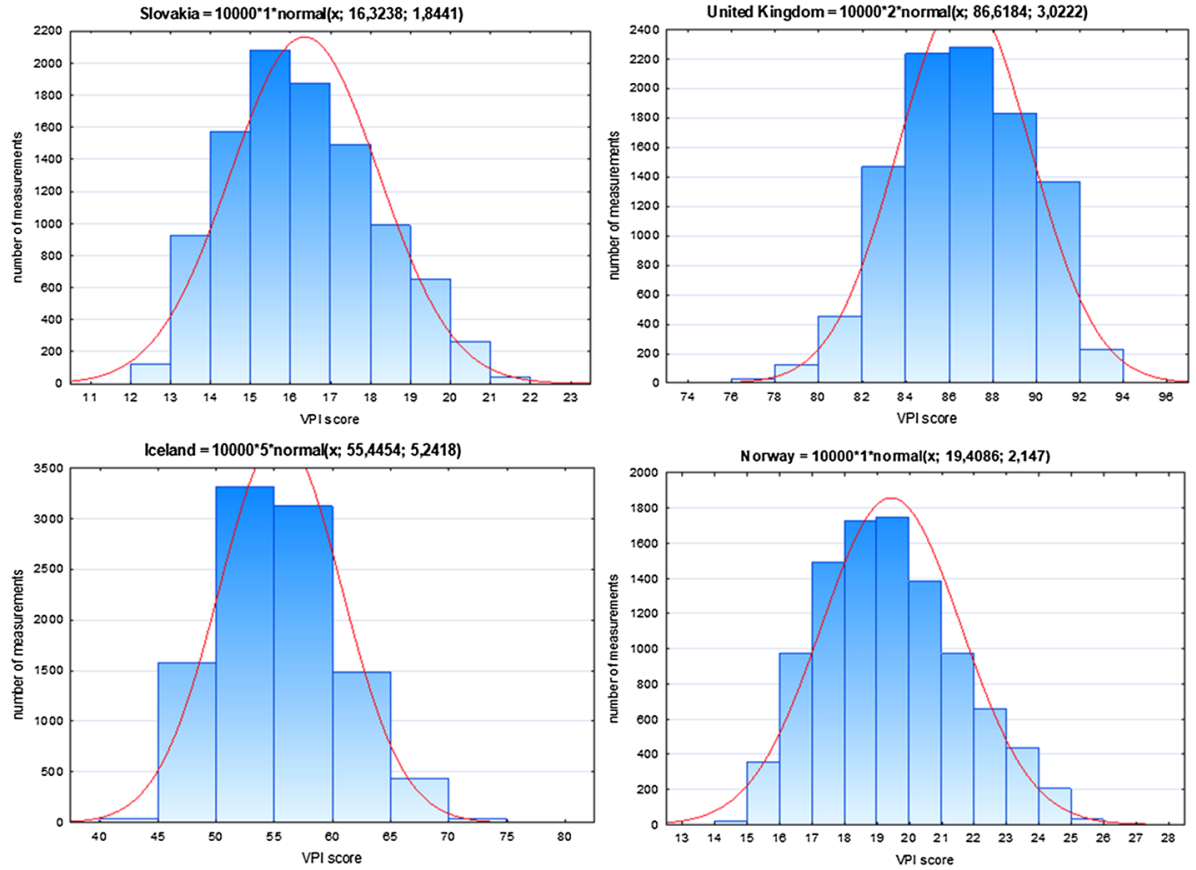

Fig. 7 (continued)

Table 3 Data sources

\begin{tabular}{lll}
\hline Country & Source & Notes \\
\hline Austria & FMA Finanzmarktaufsicht (Financial & Assets, number of members and contributions in per- \\
& Market Authority) & sonal plans PZV in the form of insurance contracts and \\
& pension funds & Assets and number of members in occupational plans \\
& Pensionskassen & Lack of information on other occupational plans
\end{tabular}

Eurostat (Structural Business Statis- Annual contributions to Pensionkassen. Due to the break tics dataset)

Belgium AFDM Autoriteit voor Financiële Diensten en Markten (The Financial Services and Markets Authority)

Assuralia

ODP Open Data Portal data.gov.be in time series, the estimated value in 2013 is equal to the contribution level in 2012

Assets, membership and contributions in occupational plans in the form of pension funds

Assets in personal plans in the form of group insurance contracts

Assets and contributions in occupational plans in the form of group insurance contracts of "Branch 21" type.

Lack of information on the membership in the occupational plans in the form of group insurance contracts of "Branch 21" type

Members and contributions in personal plans in the form of insurance contracts and pension funds

$B N B$ Bangue National de Belgique Assets in personal plans in the form of pension funds

(National Bank of Belgium) 
Table 3 (continued)

\begin{tabular}{|c|c|}
\hline Country & Source \\
\hline Bulgaria & $\begin{array}{l}\text { FSC Комисия за финансов надзор } \\
\text { (Financial Supervision Commis- } \\
\text { sion) }\end{array}$ \\
\hline Croatia & $\begin{array}{l}\text { HANFA Hrvatska agencija za nadzor } \\
\text { financijskih usluga (Croatian } \\
\text { Financial Services Supervisory } \\
\text { Agency) }\end{array}$ \\
\hline Czechia & $\begin{array}{l}\text { APS CR Asociace penzijních } \\
\text { společností ČR (The Association } \\
\text { of Pension Funds of the Czech } \\
\text { Republic) }\end{array}$ \\
\hline Denmark & $\begin{array}{l}\text { DFSA Finanstilsynet (Danish Finan- } \\
\text { cial Supervisory Authority) } \\
\text { OECD (OECD Dataset: Funded } \\
\text { Pensions Indicators) }\end{array}$ \\
\hline France & $\begin{array}{l}\text { DREES La Direction de la } \\
\text { recherche, des études, de } \\
\text { l'évaluation et des statistiques, } \\
\text { Ministère des Affaires sociales } \\
\text { et de la Santé (The Directorate } \\
\text { of Research, Studies, Evaluation } \\
\text { and Statistics, Ministry of Social } \\
\text { Affairs and Health) }\end{array}$ \\
\hline
\end{tabular}

Hungary $\quad M N B$ The Magyar Nemzeti Bank (National Bank of Hungary)

EIOPA European Insurance and Occupational Pensions Authority

Iceland $O E C D$ (OECD Dataset: Funded Pensions Indicators)
FME Fjármálaeftirlitið (Financial Supervisory Authority)

Italy COVIP Commissione di Vigilanza sui Fondi Pensione (Pension Fund Supervision Commission)

\section{Latvia $\quad F K T K$ Finanšu un kapitāla tirgus komisja (Financial and Capital Market Commission)}

Lithuania OSP Oficialiosios Statistikos Portalas (Official Statistics Portal)

Norway $F N$ Finans Norge (Finance Norway)

SSB Statistisk sentralbyrå (Statistics Norway)
Notes

Full information on the personal plans (VPF) and occupational plans (VPFOS)

Full information on the personal plans in the form of open pension funds (ODMF) and the occupational plans in the form of closed pension funds (ZDMF)

Full information on the transformed funds (Transformované fondy) and participating funds (Účastnické fondy). The analysis excludes retirement funds (Di̊chodové fondy) as the part of the II pillar

Membership and contributions in personal plans in the form of life insurance

Assets in the personal plans

Full information on plans in the schemes under article 82 of the French General Tax Code, PERCO, Madelin, PERP, PREFON as well as other minor schemes classified by DREES as voluntary. The schemes under article 39 and 83 are not included as they do not meet the adapted criteria of voluntary programs

Full information on personal plans in the form of pension funds

Lack of data on occupational plans (due to the minor importance they can be neglected)

Assets and membership in the NYESZ accounts Lack of data on contributions to NYESZ accounts

Assets and contributions in personal plans

Membership in personal plans

Full information on pension plans in the form of open and closed pension funds, "old" pension funds, and personal PIP plans (old and new). Open pension funds are classified as personal, as the split between personal and occupational was impossible

Information on the open (personal) and closed (occupational) pension funds. As the split between these two types is impossible, due to the small number of the closed funds they were included as open funds

Full information on pension funds

Lack of data on insurance contracts

Membership in personal plans in the form of life insurance (IPA, IPS, life annuity)

Assets and contributions in personal plans 
Table 3 (continued)

\begin{tabular}{|c|c|c|}
\hline Country & Source & Notes \\
\hline Poland & $\begin{array}{l}K N F \text { Komisja Nadzoru Finansowego } \\
\text { (Financial Supervision Authority) }\end{array}$ & $\begin{array}{l}\text { Full information on occupational (PPE) and personal } \\
\text { (IKE, IKZE) pension plans }\end{array}$ \\
\hline Portugal & $\begin{array}{l}\text { ASF Autoridade de Supervisão de } \\
\text { Seguros e Fundos de Pensões } \\
\text { (Insurance and Pension Funds } \\
\text { Supervisory Authority) }\end{array}$ & $\begin{array}{l}\text { Full information on occupational pension plans in the } \\
\text { form of closed and open pension funds } \\
\text { Full information on personal pension plans in the form of } \\
\text { open pension fund, as well as the pension funds under } \\
\text { PPA and PPR schemes, and investment funds and } \\
\text { insurance contracts under PPR scheme } \\
\text { Lack of information on plans in the form of investment } \\
\text { funds under PPA scheme } \\
\text { Lack of data on occupational plans in the form of group } \\
\text { insurance contracts (marginal importance) }\end{array}$ \\
\hline Romania & $\begin{array}{l}\text { APAPR Asociatia pentru Pensiile } \\
\text { Administrate Privat din Romania } \\
\text { (The Romanian Pension Funds' } \\
\text { Association) }\end{array}$ & Full information on occupational pension plans \\
\hline \multirow[t]{2}{*}{ Slovakia } & $\begin{array}{l}\text { NBS Národná banka Slovenska } \\
\text { (National Bank of Slovakia) }\end{array}$ & $\begin{array}{l}\text { Assets and contributions to pension plans in the form } \\
\text { of pension funds (DDS). Data include both, voluntary } \\
\text { contributions and mandatory employer's contribution } \\
\text { in the case of hazardous professions, as the split is } \\
\text { impossible }\end{array}$ \\
\hline & $\begin{array}{l}\text { MPSVR Ministerstvo práce, sociál- } \\
\text { nych vecí a rodiny (The Ministry } \\
\text { of Labour, Social Affairs and Fam- } \\
\text { ily of the Slovak Republic) }\end{array}$ & $\begin{array}{l}\text { Membership in DDS plans. Data include both, voluntary } \\
\text { contributions and mandatory employer's contribution } \\
\text { in the case of hazardous professions, as the split is } \\
\text { impossible }\end{array}$ \\
\hline \multirow[t]{4}{*}{ Slovenia } & $\begin{array}{l}\text { ATVP Agencija za trg vrednost- } \\
\text { nih papirjev (Securities Market } \\
\text { Agency) }\end{array}$ & $\begin{array}{l}\text { Full information on pension funds (Vzajemni pokojninski } \\
\text { skladi). As the split between open and closed pen- } \\
\text { sion funds is impossible, all of them are classified as } \\
\text { occupational }\end{array}$ \\
\hline & $\begin{array}{l}A Z N \text { Agencija za zavarovalni nadzor } \\
\text { (Insurance Supervision Agency) }\end{array}$ & $\begin{array}{l}\text { Full information on the plans administered by pension } \\
\text { companies (Pokojninske družbe) }\end{array}$ \\
\hline & $\begin{array}{l}\text { MDDSZ Ministrstvo za delo, } \\
\text { družino, socialne zadeve in enake }\end{array}$ & $\begin{array}{l}\text { Membership in plans administered by insurance compa- } \\
\text { nies (Zavarovalnice). }\end{array}$ \\
\hline & $\begin{array}{l}\text { možnosti (Ministry of Labour, } \\
\text { Family, Social Affairs and Equal } \\
\text { Opportunities) }\end{array}$ & $\begin{array}{l}\text { Lack of data on assets and contributions in the plans } \\
\text { administered by insurance companies }\end{array}$ \\
\hline \multirow[t]{2}{*}{ Spain } & $\begin{array}{l}\text { INVERCO Asociación de Institu- } \\
\text { ciones de Inversión Colectiva y } \\
\text { Fondos de Pensiones (The Asso- } \\
\text { ciation of Collective Investment } \\
\text { Institutions and Pension Funds) }\end{array}$ & $\begin{array}{l}\text { Full information on personal, associated and occupa- } \\
\text { tional pension funds }\end{array}$ \\
\hline & $\begin{array}{l}\text { DGSFP Dirección General de } \\
\text { Seguros y Fondos de Pensiones, } \\
\text { Ministerio de Economía y Com- } \\
\text { petitividad (The General Direc- } \\
\text { torate of Insurance and Pension } \\
\text { Funds, Ministry of Economy and } \\
\text { Competitiveness) }\end{array}$ & $\begin{array}{l}\text { Full information on personal pension plans in the form of } \\
\text { insurance contracts (PPA) } \\
\text { Full information on occupational pension plans in } \\
\text { the form of insurance contracts (PPSE and Seguros } \\
\text { Colectivos) }\end{array}$ \\
\hline
\end{tabular}


Table 3 (continued)

\begin{tabular}{lll}
\hline Country & Source & Notes \\
\hline $\begin{array}{c}\text { United } \\
\text { King- } \\
\text { dom }\end{array}$ & $\begin{array}{c}\text { HMRC Her Majesty's Revenue and } \\
\text { Customs }\end{array}$ & Membership and contributions in personal plans \\
& ONS Office for National Statistics & Membership in occupational plans \\
& DWP Department for Work and & Contributions to occupational plans \\
Pensions & Assets in personal plans estimated on the basis of PPI \\
& PPI Pensions Policy Institute & time series up to 2010 and according to the contribu- \\
& tions growth rate \\
& Assets in occupational plans \\
& & \\
Pensions Europe www.pensionseu &
\end{tabular}

Table 4 Assets of voluntary pension plans (2013)

\begin{tabular}{|c|c|c|c|c|c|c|}
\hline \multirow[t]{2}{*}{ Country } & \multicolumn{3}{|c|}{ Assets (mln Euro) } & \multicolumn{3}{|c|}{ Assets (\% of GDP) } \\
\hline & Occupational & Personal & Total & Occupational & Personal & Total \\
\hline Austria & $17,595.1$ & 7762.0 & $25,357.1$ & 5.5 & 2.4 & 7.9 \\
\hline Belgium & $69,856.4$ & $134,879.0$ & $204,735.4$ & 17.8 & 34.3 & 52.1 \\
\hline Bulgaria & 3.7 & 344.9 & 348.6 & 0.0 & 0.8 & 0.8 \\
\hline Croatia & 64.9 & 289.5 & 354.4 & 0.2 & 0.7 & 0.8 \\
\hline Czechia & 0.0 & $10,844.4$ & $10,844.4$ & 0.0 & 7.3 & 7.3 \\
\hline Denmark & 0.0 & $59,884.8$ & $59,884.8$ & 0.0 & 23.5 & 23.5 \\
\hline France & $54,192.6$ & $40,533.9$ & $94,726.4$ & 2.6 & 1.9 & 4.5 \\
\hline Hungary & 0.0 & 5031.6 & 5031.6 & 0.0 & 5.0 & 5.0 \\
\hline Iceland & 0.0 & 2634.9 & 2634.9 & 0.0 & 22.1 & 22.1 \\
\hline Italy & $84,902.0$ & $31,503.0$ & $116,405.0$ & 5.3 & 2.0 & 7.3 \\
\hline Latvia & 0.0 & 235.7 & 235.7 & 0.0 & 1.0 & 1.0 \\
\hline Lithuania & 0.0 & 37.7 & 37.7 & 0.0 & 0.1 & 0.1 \\
\hline Norway & 0.0 & 9604.7 & 9604.7 & 0.0 & 2.6 & 2.6 \\
\hline Poland & 2264.5 & 1056.8 & 3321.3 & 0.6 & 0.3 & 0.8 \\
\hline Portugal & $14,425.0$ & $13,848.0$ & $28,273.0$ & 8.5 & 8.1 & 16.6 \\
\hline Romania & 181.5 & 0.0 & 181.5 & 0.1 & 0.0 & 0.1 \\
\hline Slovakia & 0.0 & 1351.4 & 1351.4 & 0.0 & 1.8 & 1.8 \\
\hline Slovenia & 1431.2 & 0.0 & 1431.2 & 4.0 & 0.0 & 4.0 \\
\hline Spain & $62,249.1$ & $71,634.3$ & $133,883.4$ & 6.0 & 6.9 & 13.0 \\
\hline United Kingdom & $2,225,000.0$ & $650,772.1$ & $2,875,772.1$ & 106.6 & 31.2 & 137.8 \\
\hline
\end{tabular}

VPI component (before normalization) in bold 
Table 5 Participation in voluntary pension plans (2013)

\begin{tabular}{|c|c|c|c|c|c|c|}
\hline \multirow[t]{2}{*}{ Country } & \multicolumn{3}{|c|}{ Number of plans (thous.) } & \multicolumn{3}{|c|}{$\begin{array}{l}\text { Number of plans (\% of the population } \\
15-64)\end{array}$} \\
\hline & Occupational & Personal & Total & Occupational & Personal & Total \\
\hline Austria & 762.4 & 1636.0 & 2398.4 & 13.4 & 28.7 & 42.0 \\
\hline Belgium & 1002.0 & 2483.3 & 3485.3 & 13.7 & 34.0 & 47.7 \\
\hline Bulgaria & 6.2 & 589.9 & 596.1 & 0.1 & 12.0 & 12.2 \\
\hline Croatia & 22.7 & 204.6 & 227.3 & 0.8 & 7.2 & 8.0 \\
\hline Czechia & 0.0 & 4961.2 & 4961.2 & 0.0 & 69.0 & 69.0 \\
\hline Denmark & 0.0 & 1471.1 & 1471.1 & 0.0 & 40.6 & 40.6 \\
\hline France & 3781.4 & 3032.9 & 6814.3 & 9.0 & 7.2 & 16.3 \\
\hline Hungary & 0.0 & 1344.5 & 1344.5 & 0.0 & 19.8 & 19.8 \\
\hline Iceland & 0.0 & 113.4 & 113.4 & 0.0 & 53.1 & 53.1 \\
\hline Italy & 2605.1 & 3623.7 & 6228.8 & 6.7 & 9.4 & 16.1 \\
\hline Latvia & 0.0 & 220.6 & 220.6 & 0.0 & 16.3 & 16.3 \\
\hline Lithuania & 0.0 & 34.2 & 34.2 & 0.0 & 1.7 & 1.7 \\
\hline Norway & 0.0 & 900.0 & 900.0 & 0.0 & 27.0 & 27.0 \\
\hline Poland & 375.0 & 1314.1 & 1689.1 & 1.4 & 4.9 & 6.3 \\
\hline Portugal & 165.3 & 2442.0 & 2607.3 & 2.4 & 35.4 & 37.8 \\
\hline Romania & 313.3 & 0.0 & 313.3 & 2.3 & 0.0 & 2.3 \\
\hline Slovakia & 0.0 & 883.9 & 883.9 & 0.0 & 22.8 & 22.8 \\
\hline Slovenia & 495.9 & 0.0 & 495.9 & 35.2 & 0.0 & 35.2 \\
\hline Spain & 9546.8 & 9034.0 & $18,580.8$ & 30.4 & 28.8 & 59.2 \\
\hline United Kingdom & 8100.0 & 8170.0 & $16,270.0$ & 19.4 & 19.6 & 39.1 \\
\hline
\end{tabular}

VPI component (before normalization) in bold 
Table 6 Annual contributions to voluntary pension plans (2013)

\begin{tabular}{|c|c|c|c|c|c|c|c|}
\hline \multirow[t]{2}{*}{ Country } & \multicolumn{3}{|c|}{ Contributions (mln Euro) } & \multirow[t]{2}{*}{$\begin{array}{l}\text { Contributions } \\
\text { (\% of GDP) }\end{array}$} & \multicolumn{3}{|c|}{$\begin{array}{l}\text { Contributions per plan } \\
(\% \text { of annual net earnings })^{a}\end{array}$} \\
\hline & Occupational & Personal & Total & & Occupational & Personal & Total \\
\hline Austria & 1188.0 & 1042.0 & 2230.0 & 0.7 & 5.7 & 2.3 & 3.4 \\
\hline Belgium & 6574.5 & 1968.3 & 8542.8 & 2.2 & 24.7 & 3.0 & 9.2 \\
\hline Bulgaria & 0.8 & 30.2 & 31.0 & 0.1 & 3.2 & 1.3 & 1.3 \\
\hline Croatia & 10.8 & 38.3 & 49.1 & 0.1 & 5.6 & 2.2 & 2.5 \\
\hline Czechia & 0.0 & 1388.9 & 1388.9 & 0.9 & 0.0 & 3.2 & 3.2 \\
\hline Denmark & 0.0 & 922.8 & 922.8 & 0.4 & 0.0 & 1.9 & 1.9 \\
\hline France & 5608.5 & 2441.3 & 8049.7 & 0.4 & 5.6 & 3.0 & 4.5 \\
\hline Hungary & 0.0 & 336.8 & 336.8 & 0.3 & 0.0 & 3.9 & 3.9 \\
\hline Iceland & 0.0 & 172.1 & 172.1 & 1.5 & 0.0 & 5.6 & 5.6 \\
\hline Italy & 8002.0 & 3903.0 & $11,905.0$ & 0.7 & 14.9 & 5.2 & 9.2 \\
\hline Latvia & 0.0 & 41.2 & 41.2 & 0.2 & 0.0 & 2.9 & 2.9 \\
\hline Lithuania & 0.0 & 6.9 & 6.9 & 0.0 & 0.0 & 3.4 & 3.4 \\
\hline Norway & 0.0 & 238.4 & 238.4 & 0.1 & 0.0 & 0.6 & 0.6 \\
\hline Poland & 277.9 & 210.5 & 488.4 & 0.1 & 10.0 & 2.2 & 3.9 \\
\hline Portugal & 773.0 & 1755.0 & 2528.0 & 1.5 & 36.5 & 5.6 & 7.6 \\
\hline Romania & 33.6 & 0.0 & 33.6 & 0.0 & 2.6 & 0.0 & 2.6 \\
\hline Slovakia & 0.0 & 33.4 & 33.4 & 0.0 & 0.0 & 0.5 & 0.5 \\
\hline Slovenia & 136.8 & 0.0 & 136.8 & 0.4 & 2.3 & 0.0 & 2.3 \\
\hline Spain & 3388.8 & 5928.6 & 9317.3 & 0.9 & 1.8 & 3.3 & 2.5 \\
\hline United Kingdom & $93,199.0$ & $21,662.5$ & $114,861.5$ & 5.5 & 36.2 & 8.3 & 22.2 \\
\hline
\end{tabular}

VPI component (before normalization) in bold

${ }^{\mathrm{a}}$ Annual net earnings obtained from Eurostat SES dataset 
Table 7 Voluntary Pensions Index (2013)

\begin{tabular}{|c|c|c|c|c|}
\hline \multirow[t]{2}{*}{ Country } & \multicolumn{3}{|c|}{$\begin{array}{l}\text { Scaled values of the VPI } \\
\text { components }\end{array}$} & \multirow[t]{2}{*}{ Total VPI score } \\
\hline & $\operatorname{ASSETS}_{i}$ & $P A R T_{i}$ & CONTR $_{i}$ & \\
\hline Austria & 13.1 & 70.1 & 16.9 & 33.4 \\
\hline Belgium & 86.9 & 79.5 & 46.1 & 70.8 \\
\hline Bulgaria & 1.4 & 20.3 & 6.7 & 9.4 \\
\hline Croatia & 1.4 & 13.3 & 12.7 & 9.1 \\
\hline Czechia & 12.1 & 100.0 & 15.8 & 42.6 \\
\hline Denmark & 39.1 & 67.6 & 9.6 & 38.8 \\
\hline France & 7.5 & 27.1 & 22.4 & 19.0 \\
\hline Hungary & 8.3 & 33.1 & 19.5 & 20.3 \\
\hline Iceland & 36.8 & 88.5 & 27.8 & 51.0 \\
\hline Italy & 12.1 & 26.8 & 46.2 & 28.4 \\
\hline Latvia & 1.7 & 27.2 & 14.4 & 14.4 \\
\hline Lithuania & 0.2 & 2.9 & 16.8 & 6.6 \\
\hline Norway & 4.4 & 45.0 & 2.8 & 17.4 \\
\hline Poland & 1.4 & 10.5 & 19.5 & 10.4 \\
\hline Portugal & 27.7 & 62.9 & 37.9 & 42.8 \\
\hline Romania & 0.2 & 3.8 & 12.9 & 5.7 \\
\hline Slovakia & 3.1 & 38.1 & 2.4 & 14.5 \\
\hline Slovenia & 6.6 & 58.7 & 11.7 & 25.7 \\
\hline Spain & 21.6 & 98.7 & 12.5 & 44.3 \\
\hline United Kingdom & 100.0 & 65.1 & 100.0 & 88.4 \\
\hline
\end{tabular}

\section{References}

Alessie, R., Lusardi, A., \& Kapteyn, A. (1999). Saving after retirement: evidence based on three different savings measures. Labour Economics, 6(2), 277-310.

Alonso-Fernandez, J. J., Meneu-Gaya, R., Devesa-Carpio, E., Devesa-Carpio, M., Dominguez-Fabian, I., \& Encinas-Goenechea, B. (2017). From the replacement rate to the synthetic indicator: A global and gender measure of pension adequacy in the European Union. Social Indicators Research. https ://doi.org/10.1007/s11205-017-1653-x.

Ando, A., \& Modigliani, F. (1963). The "life cycle" hypothesis of saving: Aggregate implications and tests. The American Economic Review, 53(1), 55-84. https://doi.org/10.1126/scien ce.151.3712.867-a.

Attanasio, O. P., \& Rohwedder, S. (2003). Pension wealth and household saving: Evidence from pension reforms in the United Kingdom. American Economic Review. https://doi.org/10.1257/0002828033 22655419.

Bailliu, J. N., \& Reisen, H. (1998). Do funded pensions contribute to higher aggregate savings? A crosscountry analysis. Weltwirtschaftliches Archiv, 134(4), 692-711. https://doi.org/10.1007/bf02773293.

Bajtelsmit, V. L., Rappaport, A., \& Foster, L. (2013). New insights on the measurement of benefit adequacy. Retirement Management Journal, 3(2), 33-42.

Blake, D. (2006). Pension economics. Chichester: Wiley.

Bonoli, G. (1997). Classifying welfare states: A two-dimension approach. Journal of Social Policy, 26(3), 351-372.

Borella, M., \& Fornero, E. (2009). Adequacy of pension systems in Europe: An Analysis based on comprehensive replacement rates. ENEPRI Research Report, 68.

Bovenberg, L., \& Van Ewijk, C. (2012). The future of multipillar pension systems. CESifo DICE Report, 10(4), 16-20. https://doi.org/10.2139/ssrn.1935307. 
Carone, G., Eckefeldt, P., Giamboni, L., Laine, V., \& Pamies, S. (2016). Pension reforms in the EU since the early 2000's: Achievements and challenges ahead. European Economy Discussion Papers 42, Brussels.

Crespy, A. (2016). Welfare markets in Europe: The democratic challenge of European integration. London: Palgrave Macmillan.

De Deken, J. (2013). Towards an index of private pension provision. Journal of European Social Policy, 23(3), 270-286. https://doi.org/10.1177/0958928713480063.

Disney, R. (2006). Household saving rates and the design of public pension programmes: Cross-country evidence. National Institute Economic Review, 198, 61-74. https://doi.org/10.1177/0027950106 074040.

Dushi, I., \& Webb, A. (2004). Household annuitization decisions: Simulations and empirical analyses. Journal of Pension Economics and Finance, 3(2), 109-143. https://doi.org/10.1017/s1474747204001696.

Ebbinghaus, B. (2011). The varieties of pension governance: Pension privatization in Europe. Oxford: Oxford University Press. https://doi.org/10.1093/acprof:oso/9780199586028.001.0001.

Ebbinghaus, B. (2015). The privatization and marketization of pensions in Europe: A double transformation facing the crisis. European Policy Analysis, 1(1), 56-73. https://doi.org/10.18278/epa.1.1.5.

Esping-Andersen, G. (1990). Three worlds of welfare state capitalism. Cambridge: Polity Press.

European Commission. (2015a). The 2015 pension adequacy report: Current and future income adequacy in old age in the EU. Luxembourg: European Commission.

European Commission. (2015b). The 2015 ageing report. Economic and budgetary projections for the 28 EU Member States (2013-2060). Brussels: Directorate-General for Employment, Social Affairs and Inclusion Social Protection Committee.

Feldstein, M. (1980). International differences in social security and saving. Journal of Public Economics, 14(2), 225-244. https://doi.org/10.1016/0047-2727(80)90041-9.

Feldstein, M. (1996). Social security and saving: New time series evidence. National Tax Journal, 49(2), 151-164. https://doi.org/10.3386/w5054.

Feng, J., He, L., \& Sato, H. (2011). Public pension and household saving: Evidence from urban China. Journal of Comparative Economics, 39(4), 470-485. https://doi.org/10.1016/j.jce.2011.01.002.

Fernández-López, S., Otero, L., Vivel, M., \& Rodeiro, D. (2010). What are the driving forces of individuals' retirement savings? Finance a Uver - Czech Journal of Economics and Finance, 60(3), 226-251.

Grech, A. G. (2013). How best to measure pension adequacy. Centre for Analysis of Social Exclusion Discussion Paper, (172).

Inkmann, J., Lopes, P., \& Michaelides, A. (2011). How deep is the annuity market participation puzzle? Review of Financial Studies, 24(1), 279-319. https://doi.org/10.1093/rfs/hhq080.

Kohli, M., \& Arza, C. (2008). Pension reform in Europe: Politics, policies and outcomes. London: Routledge.

Lachowska, M., \& Myck, M. (2015). The effect of public pension wealth on saving and expenditure. IZA Discussion Paper, 8895. https://doi.org/10.17848/wp15-223.

Le Blanc, J. (2011). The third pillar in Europe: Institutional factors and individual decisions. Deutsche Bundesbank Discussion Paper, Series 1: Economic Studies (Vol. 9). Frankfurt am Main: Deutsche Bundesbank.

Marcinkiewicz, E., \& Chybalski, F. (2014). How to measure and compare pension expenditures in crosscountry analyses? Some methodological remarks. International Journal of Business and Management, II(4), 43-59.

Marcinkiewicz, E., \& Chybalski, F. (2017). A new proposal of pension regimes typology: Empirical analysis of the OECD countries. Journal of Economic Policy Reform. https://doi.org/10.1080/17487 870.2016.1276454.

Mendenhall, W., Reinmuth, J. E., Beaver, R., \& Duhan, D. (1982). Statistics for management and economics. Boston: Duxbury Press.

Meyer, T. (2014). Beveridge not Bismarck! European lessons for men's and women's pensions in Germany. Berlin: Friedrich-Ebert-Stiftung.

Meyer, T., Bridgen, P., \& Riedmüller, B. (2007). Private pensions versus social inclusion? Non-state provision for citizens at risk in Europe. Cheltenham: Edward Elgar.

Modigliani, F., \& Brumberg, R. (1954). Post-Keynesian economics. In K. Kurihara (Ed.), Utility analysis and the consumption function: An interpretation of cross-section data (Vol. 6). New Brunswick: Rutgers University Press. https://doi.org/10.4324/9781315016849.

Natali, D. (2017). The new pension mix in Europe: Recent reforms, their distributional effects and political dynamics. Brussels: P.I.E-Peter Lang S.A.

OECD. (2015a). Pensions at a Glance 2015: OECD and G20 indicators. Paris: OECD Publishing.

OECD. (2015b). Stocktaking of the tax treatment of funded private pension in OECD and EU countries. Paris: OECD Publishing. 
OECD. (2015c). The tax treatment of funded private pension. OECD and EU country profiles. Paris: OECD Publishing.

OECD. (2016). Pension markets in focus. Paris: OECD Publishing.

Rhodes, M., \& Natali, D. (2003). Welfare regimes and pension reform agendas. Paper given at the conference "Pension Reform in Europe: Shared Problems, Sharing Solutions", London School of Economics and Political Science, 5 December 2003. http://www.lse.ac.uk/europeanInstitute/research/hellenicOb servatory/pdf/pensions_conference/Rhodes-Pensions.pdf. Accessed 15 June 2017.

Seeleib-Kaiser, M. (2008). Welfare state transformations in comparative perspective: Shifting boundaries of "public" and "private" social policy. In M. Seeleib-Kaiser (Ed.), Welfare state transformations (pp. 1-13). London: Palgrave Macmillan.

Soede, A., \& Vrooman, C. (2008). A comparative typology of pension regimes. ENEPRI Research Reports, (54).

Sommer, M. (2007). Saving motives and the effectiveness of tax incentives: An analysis based on the demand for life-insurance in Germany. Mannheim Research Institute for the Economics of Aging, Working Paper 125-2007.

Vaillancourt, F., Lammam, C., Herzog, I., \& Ebrahimi, P. (2015). Compulsory government pensions vs. private savings. The effect of previous expansion to the Canada pension plan. Vancouver: Fraser Institute.

Wolf, F., Zohlnhöfer, R., \& Wenzelburger, G. (2014). The politics of public and private pension generosity in advanced democracies. Social Policy and Administration, 48(1), 86-106. https://doi.org/10.1111/ spol.12008.

Zohlnhöfer, R., Wolf, F., \& Wenzelburger, G. (2013). Political parties and pension generosity in times of permanent austerity. World Political Science Review, 9(1), 291-318. https://doi.org/10.1515/ wpsr-2013-0012. 